\title{
P-piller reduserer risikoen for endometriekreft
}

Bruk av p-piller har forhindret svært mange tilfeller av endometriekreft.

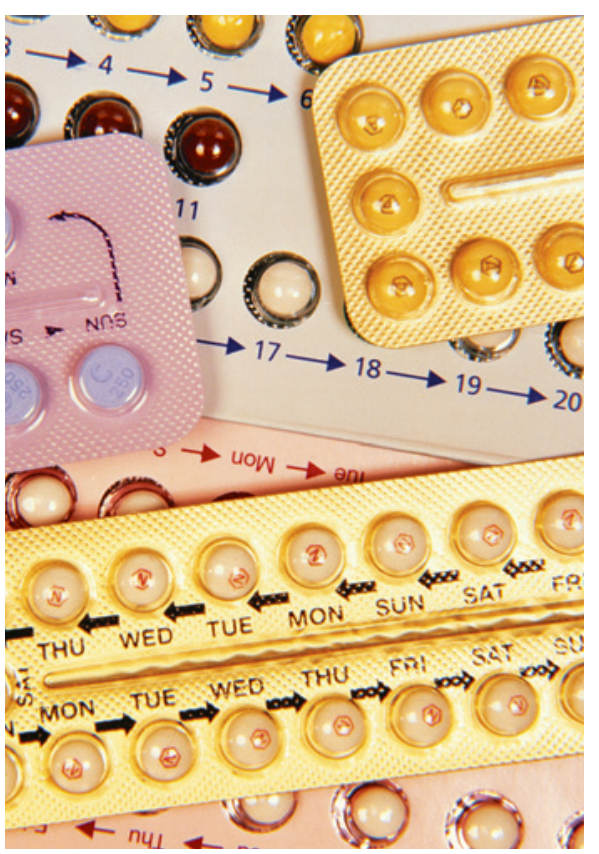

Illustrasjonsfoto: Science Photo Library
Østrogeninnholdet i p-piller er blitt gradvis redusert på grunn av flere velkjente bivirkninger. Har dette ført til endringer i forekomsten av endometriekreft? En nylig publisert metaanalyse av data fra 36 epidemiologiske studier viser at p-piller reduserer risikoen for endometriekreft - uavhengig av pillens østrogeninnhold (1).

Den beskyttende effekten av p-piller øker jo lenger man bruker dem - risikoratioen etter fem års bruk var 0,76 , og etter $10-15$ års bruk var risikoen halvert. Selv etter avsluttet bruk av p-piller har kvinner en relativ beskyttelse i mange år. Ifølge forfatternes beregninger kan totalt rundt 400000 tilfeller av endrometriekreft være forhindret som følge av p-pillebruk.

- Epidemiologiske metastudier som dette antyder at det ikke bare er en assosiasjon, men også en mulig årsakssammenheng mellom p-pillebruk og endometriekreft, sier overlege professor Helga B. Salvesen ved Haukeland universitetssykehus og Universitetet i Bergen. - Dette underbygges av studiens størrelse og omfattende korrigering for andre risikofaktorer knyttet til utvikling av endometriekreft, som kroppsmasseindeks, antall barn (som mål på fertilitet), annen hormontablettbruk og røyking, sier hun.

- Funnet støttes av biologisk kunnskap om hvordan livmorslimhinnen stimuleres og cellene vokser og støtes ut. P-pillene som var brukt i den aktuelle studien, var hovedsakelig kombinasjonspiller med østrogen og progesteron. Én mulig forklaring er at kombinasjonsbehandling reduserer høy og ensidig østrogendrevet celleproliferasjon i livmorslimhinnen. Tilskudd av gestagen ved hormonbehandling av menopausale kvinner gir lavere forekomst av livmorkreft sammenliknet med ensidig østrogensubstitusjonsbehandling (2). Studier av mekanismen for hvordan bruk av kombinasjons-p-piller beskytter mot endometriekreft kan gi viktig kunnskap som er relevant for kliniske utprøvningsstudier for å motvirke den observerte økningen i forekomst av endometriekreft, forteller Salvesen.

\section{Inge Rasmus Groote}

Tidsskriftet

\section{Litteratur}

1. Collaborative Group on Epidemiological Studies on Endometrial Cancer. Endometrial cancer and oral contraceptives: an individual participant metaanalysis of 27 ?276 women with endometrial cancer from 36 epidemiological studies. Lancet Oncol 2015; 16: 1061-70.

2. Beral V, Bull D, Reeves G. Endometrial cancer and hormone-replacement therapy in the Million Women Study. Lancet 2005; 365: 1543-51.

\section{Hvordan gir influensavaksiner narkolepsi?}

\section{Hos noen pasienter danner influensa A(H1N1)-vaksinen antistoffer som reagerer med reseptoren for hypokretin, et nevropetid i hypothalamus som regulerer søvn og våkenhet.}

Etter ett års bruk av influensa $\mathrm{A}(\mathrm{H} 1 \mathrm{~N} 1)$ vaksinen hos over 30 millioner mennesker i Norge og resten av Europa kom det inn rapporter om vaksineassosiert narkolepsi, særlig hos unge mennesker. Dette skyldes antakelig autoimmune mekanismer. Det viser en nylig publisert studie (1).

Omfattende bioinformatikkanalyser viste flere likheter i en sekvens på 12 aminosyrer mellom influensavirusets og vaksinens nukleoprotein og den ekstracellulære delen av hypokretinreseptor 2, en hypothalamusreseptor som er med i reguleringen av søvn og våkenhet og som antas å være involvert $\mathrm{i}$ utviklingen av narkolepsi. Et visst vevstypeallel, HLADQB1*06:02, som disponerer for narkolepsi, finnes også hos pasienter med vaksineassosiert narkolepsi. Antistoffer som bandt seg til både influensanukleoprotein og hypokretinreseptor 2, ble påvist hos mange slike pasienter. Men antistoffene var ikke, eller bare forbigående, til stede hos andre millioner brukere av en alternativ vaksine som hadde mye mindre nukleo- protein og en mye lavere, om noen, risiko for utvikling av narkolepsi.

- Dette er en studie med spennende resultater, sier professor Ludvig M. Sollid ved Senter for immunregulering, Universitetet i Oslo. - Resultatene tyder på at det ikke er en immunrespons mot hypokretinreseptor som alene driver utviklingen av narkolepsi. Årsaken er heller immunresponsen mot influensavirus, særlig mot virusantigen i influensa $A(\mathrm{H} 1 \mathrm{~N} 1)-$ vaksinen, med påfølgende danning av kryssreagerende og autoreaktive antistoffer. Narkolepsipasienter kjennetegnes ved at de har mangel på hypokretin. Hvorfor antistoffer mot hypokretinreseptor skal føre til mangel på hypokretin, er imidlertid ikke lett å forstå, sier Sollid.

\section{Haakon B. Benestad}

Universitetet i Oslo

\section{Litteratur}

1. Ahmed SS, Volkmuth W, Duca J et al. Antibodies to influenza nucleoprotein cross-react with human hypocretin receptor 2. Sci Transl Med 2015; 7 294 ra105.

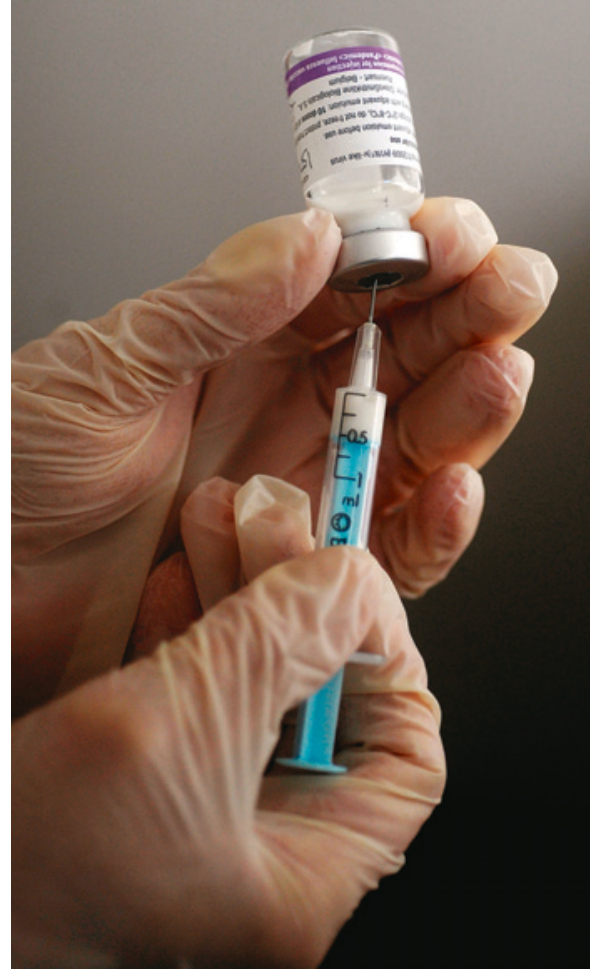

Illustrasjonsfoto: AFP/NTB scanpix 